Jurnal Penelitian dan Karya Ilmiah

\title{
KUALITAS PELAYANAN IZIN MENDIRIKAN BANGUNAN (IMB) ANTARA BADAN PELAYANAN PERIZINAN TERPADU KOTA BANDUNG DAN KANTOR PELAYANAN PERIZINAN TERPADU KOTA CIMAHI
}

\author{
1 Irvan Arif Kurniawan \\ 1 Universitas Islam Syekh-Yusuf \\ Email:irfanarifk@unis.ac.id
}

\begin{abstract}
Abtsrak
Kualitas pelayanan perizinan merupakan cerminan dari kinerja aparatur birokrasi pemerintahan.Badan Pelayanan Perizinan Terpadu (BPPT) Kota Bandung dan Kantor Pelayanan Perizinan Terpadu (KPPT) Kota Cimahi merupakan lembaga pemerintah yang menangani pelayanan perizinan terpadu satu pintu. Tujuannya untuk memberikan kualitas pelayanan perizinan yang baik dalam memangkas birokrasi perizinan yang panjang. Tujuan penelitian ini adalah untuk membandingkan bagaimana kualitas pelayanan perizinan, khususnya pelayanan Izin Mendirikan Bangunan di Badan Pelayanan Perizinan Terpadu (BPPT) Kota Bandung dengan Kantor Pelayanan Perizinan Terpadu (KPPT) Kota Cimahi. Penelitian ini menggunakan teori dimensi kualitas pelayanan yang dikemukakan oleh Parasuraman. Dimana kelima dimensi ini digunakan untuk mengukur sejauh mana kualitas pelayanan IMB antara BPPT Kota Bandung dengan KPPT Kota Cimahi. Adapun hipotesis didalam penelitian ini adalah, terdapat perbedaan kualitas pelayanan IMB antara BPPT Kota Bandung dengan KPPT Kota Cimahi.
\end{abstract}

Kata kunci: Kualitas Pelayanan, Perizinan, IMB 


\section{A. PENDAHULUAN}

Baik buruknya suatu kualitas pelayanan izin mendirikan bangunan (IMB) dapat dilihat dari beberapa sudut pandang perspektif. Kualitas pelayanan IMB dapat dari perspektif administrasi, perspektif organisasi, perspektif sumber daya manusia (SDM), dan perspektif kinerja. Apabila dilihat dari sudut pandang perspektif administrasi maka biaya pelayanan IMB dapat dikenakan biaya yang murah dan tidak mahal. Dilihat dari sudut pandang perspektif organisasi, tugas aparatur negara didalam pelayanan IMB tidak tumpang tindih, dalam artian sudah ada tugas dan fungsinya masing-masing tanpa harus memegang jabatan rangkap. Dari sudut pandang perspektif SDM, terdapat sumber daya manusia yang memadai, dalam arti jumlah pegawai dan beban tugas harus sebanding, dan kapasitas SDM seperti skill dan keterampilan juga harus terlatih dan siap digunakan. Dan bila dilihat dari perspektif kinerja maka kualitas pelayanan IMB harus dibarengi dengan efisiensi, dalam arti proses pelayanan IMB tidak berbelit-belit dan mudah untuk dijalani, sehingga masyarakat yang akan mengajukan IMB tidak terlanyani dengan baik.

Maka dari itu, peneliti akan melakukan kajian penelitian terkait kualitas pelayanan IMB yang sampai saat ini selalu menjadi perhatian publik. Penelitian kualitas pelayanan Izin Mendirikan Bangunan (IMB) menggunakan ide atau gagasan yang berbeda. Penelitian ini dilakukan dengan cara melakukan studi kompartif, yakni membandingkan kualitas pelayanan izin mendirikan bangunan (IMB) di BPPT Kota Bandung dan KPPT Kota Cimahi. Dengan demikian, berdasarkan pemaparan dari fenomena yeng telah diuraikan dilatar belakang tersebut, maka penelitian ini akan dilakukan untuk mencoba dan melihat bagaimana studi komparatif antara pelayanan perizinan terpadu satu pintu di Kota Bandung dan Kota Cimahi, dengan judul penelitian: Studi Komparatif Kualitas Pelayanan Izin Mendirikan Bangunan (IMB) (Studi di BPPT Kota Bandung dan KPPT Kota Cimahi).

\section{B. TINJAUAN PUSTAKA}

Kualitas pelayanan merupakan suatu kondisi dinamis yang dapat berpengaruh dengan produk, jasa, manusia, proses dan lingkungan atau melebihi harapan (Tjiptono, 1995:14). Dari definisi tersebut dapat dikatakan kualitas pelayanan sebagai upaya untuk memenuhi kebutuhan dan keinginan pelanggan dalam mengimbangi harapan pelanggan. Kualitas pelayanan juga juga dapat dikatakan sebagai perbandingan persepsi masyarakat dalam menggunakan sebuah layanan sesuai dengan 
harapan masyarakat terhadap atribut-atribut pelayanan di suatu perusahaan. Jika kualitas pelayanan dapat diterima dan dirasakan maafaatnya, sesuai dengan yang diharapkan, maka kualitas pelayanan tersebut dapat dikatakan baik dan memuaskan. Jika jasa atau pelayanan diterima melebihi dari yang diharapkan pelanggan, maka dapat dikatakan kualitas pelayanan tersebut sangan baik dan berkualitas. Sedangkan jasa atau pelayanan yang diterima pelanggan lebih rendah dari yang diharapkan, maka kualitas pelayanan tersebut dinilai buruk.

Zeithaml, et al. (1990:21) mengemukakan ada 10 (sepuluh) dimensi yang harus diperhatikan dalam melihat tolok ukur kualitas pelayanan publik, yaitu:

1) Tangible, terdiri atas fasilitas fisik, peralatan, personil dan komunikasi.

2) Realiable, terdiri dari kemampuan unit pelayanan dalam menciptakan pelayanan yang dijanjikan dengan tepat.

3) Responsiveness, kemauan untuk membantu konsumen bertanggung jawab terhadap kualitas pelayanan yang diberikan.

4) Competence, tuntutan yang dimilikinya, pengetahuan dan keterampilan yang baik oleh aparatur dalam memberikan pelayanan.

5) Courtesy, sikap atau perilaku ramah, bersahabat, tanggap terhadap keinginan konsumen serta mau melakukan kontak atau hubungan pribadi.

6) Credibility, sikap jujur dalam setiap upaya menarik kepercayaan masyarakat.

7) Security, jasa pelayanan yang diberikan harus bebas dari berbagai bahaya dan resiko.

8) Acces, terdapat kemudahan untuk mengadakan kontak dan pendekatan.

9) Communication, kemauan pemberi pelayanan untuk mendengarkan suara, keinginan atau aspirasi pelanggan, sekaligus kesediaan untuk selalu menyampaikan informasi baru kepada masyarakat.

10) Understanding the customer, melakukan segala usaha untuk mengetahui kebutuhan pelanggan.

Selanjutnya Parasuraman dkk. (1988:21) melakukan kembali penelitian pada kelompok fokus (Focus group), baik pengguna maupun penyedia jasa. Akhirnya ditemukan hasil, bahwa terdapat hubungan yang sangat kuat antara Communication, Competence, Credibility, Courtesy, and Security yang kemudian dikelompokkan menjadi satu dimensi yaitu assurance. Demikian pula halnya mereka yang menemukan hubungan yang sangat kuat diantara acces dan understanding yang kemudian 
digabung menjadi dimensi emphaty. Akhirnya di kemukakan lima dimensi kualitas jasa yang di kenal sebagai SERVQUAL (Service Quality). Kelima dimensi tersebut adalah:

1) Tangibles (bukti langsung), meliputi fasilitas fisik, perlengkapan, penampilan pegawai, dan sarana komunikasi.

2) Reliability (kehandalan), kemampuan memberikan pelayanan yang dijanjikan dengan cepat dan memuaskan.

3) Responsiveness (daya tangkap), keinginan para staf untuk membantu pelanggan dan memberikan pelayanan dengan tanggap.

4) Assurance (jaminan), kemampuan, kesopanan, dan para staf dapat dipercaya, dan percaya diri.

5) Emphaty (empati), kemudahan dalam melakukan hubungan, perhatian individu dalam memahami kebutuhan pelanggan.

(Parasuraman dkk, 1988:21)

Berdasarkan dari pengertian yang telah dikemukakan di atas, maka untuk menciptakan pelayanan yang berkualitas yang dilaksanan oleh organisasi pemerintah atau swasta, harus mengacu kepada syaratsyarat tersebut. Selama ini ada anggapan masyarakat, bahwa kualitas pelayanan yang diberikan oleh pemerintah tidak baik dan tidak berkualitas. Hal ini dapat dilihat di media massa baik cetak maupun elektronik. Oleh karena itu, dibutuhkan suatu komitmen dan kerja keras dari aparat pemerintah selaku penyelenggara pelayanan publik dalam memberikan pelayanan publik kepada masyarakat. Kepuasan utama merupakan tujuan utama dari kualitas pelayanan publik.

\section{METODE PENELITIAN}

Metode yang digunakan didalam penelitian ini adalah metode kuantitatif, dengan menggunakan teknik survey. Adapun populasi didalam penelian ini adalah individu masyarakat yang sudah menggunakan layanan IMB pada tahun 2014 di Badan Pelayanan Perizinan Terpadu Kota Bandung yang berjumlah 4520 orang dan Kantor Pelayanan Perizinan Terpadu Kota Cimahi yang berjumlah 332 orang. Adapun penentuan sampel penelitian ini menggunakan Probability Sampling dengan teknik Simple Random Sampling dengan rumus perhitungan besaran (Bungin, 2005:105). Hasil dari perhitungan tersebut memperoleh responden sebanyak 95 responden dari BPPT Kota Bandung dan 76 responden dari KPPT Kota Cimahi. Teknik pengumpulan data didalam penelitian ini menggunakan kuesioner. Dengan menggunakan perhitungan statistik untuk analisi data. Perhitungan statistik ini 
menggunakan SPSS 19. Adapun operasional variable dalam penelitian ini dibatasi pada lima dimensi kualitas pelayanan publik yang meliputi: Tangible, Reliability, Responsiveness, Assurance dan Empathy. Kelima dimensi tersebut digunakan untuk mengukur perbandingan kualitas pelayanan publik di BPPT Kota Bandung dengan KPPT Kota Cimahi.

\section{HASIL DAN PEMBAHASAN PENELITIAN}

Hasil dari penelitian studi komparatif ini melihat dari 5 (lima) dimensi dalam mengukur kualitas pelayanan izin mendirikan bangunan (IMB) di BPPT Kota Bandung dan Kota Cimahi. Kelima dimensi tersebut terdiri dari dimensi tangible, dimensi reliability, dimensi responsiveness, dimensi assurance, dan dimensi emphaty.

1. Dimensi Tangible (Bukti Fisik)

Pada dimensi tangible kualitas pelayanan IMB di Badan Pelayanan Perizinan Terpadu (BPPT) Kota Bandung dan Kantor Pelayanan Perizinan Terpadu (KPPT) Kota Cimahi dilihat dari bukti fisik. Bukti fisik yang meliputi kenyamanan fisik gedung, kerapihan dan kebersihan, kecukupan ruangan, kelengkapan peralatan, kerapihan dan kebersihan penampilan petugas, keramahan dan kesopanan petugas layanan, dan kemudahan dan ketersediaan formulir. Baik buruknya kualitas pelayanan IMB pada bukti fisik (tangible) dapat dirasakan oleh pengguna layanan dari ketujuh indikator tersebut. Oleh karena itu kualitas pelayanan IMB perlu memperhatikan bukti fisik (tangible).

Dari hasil penelitian yang sudah dilakukan baik di BPPT Kota Bandung dan KPPT Kota Cimahi terdapat perbedaan pada dimensi tangible. Perbedaan yang paling menonjol kualitas pelayanan antara BPPT Kota Bandung dan KPPT Kota Cimahi pada dimensi tangible adalah kelengkapan peralatan pelayanan. Kelengkapan peralatan pelayanan meliputi penggunaan teknologi informasi. Dimana penggunaan teknologi digunakan untuk kelancaran pelayanan perizinan. BPPT Kota Bandung pada dimensi tangible memiliki keunggulan dalam penggunaan teknologi informasi. Dimana sistem layanan perizinananya sudah menggunakan pendekatan teknologi informasi dan terus mengalami perkembangan. Jadi didalam dimensi tangible, kelengkapan peralatan pelayanan dengan pendekatan teknologi sangat penting untuk kelancaran pelayanan perizinan terpadu satu pintu. Disamping untuk mengikuti perkembangan teknologi saat ini, juga untuk mempermudahkan masyarakat dalam menggunakan layanan perizinan. 
2. Dimensi Reliability (kehandalan)

Pada dimensi reliability, kualitas pelayanan dilihat dari kemampuan penyelenggara pelayanan perizinan dalam memberikan pelayanan yang dijanjikan dengan cepat dan memuaskan. Dimensi reliability meliputi standar pelayanan, ketepatan waktu pemberian pelayanan, peyimpanan dokumen/berkas layanan, kecepatan petugas layanan dalam memberikan pelayanan, penerapan jadwal pelayanan tepat waktu, dan kemudahan penyelesaian masalah pelayanan IMB. Pada dimensi reliability, keenam indikator ini yang dirasakan oleh pengguna layanan dari kualitas pelayanan IMB. Oleh karena itu pada dimensi reliability, keenam indikator ini perlu diperhatikan oleh penyelenggara pelayanan publik, baik itu oleh BPPT Kota Bandung maupun di KPPT Kota Cimahi.

Berdasarkan dari hasil penelitian yang diperoleh, pada dimensi reliability (kehandalan) yang dilakukan di BPPT Kota Bandung maupun di KPPT Kota Cimahi terdapat perbedaan kualitas pelayanan perizinan. Perbedaan pelayanan IMB di BPPT Kota Bandung dan KPPT Kota Cimahi pada dimensi reliability terletak pada standar pelayanan yang diberikan. Dimana standar pelayanan yang diberikan menggunakan pendelatan teknologi informasi, seperti yang dilakukan oleh BPPT Kota Bandung. Teknologi informasi yang digunakan oleh BPPT Kota Bandung, digunakan untuk membantu petugas layanan dalam memberikan layanan secara kepada pengguna layanan. Penggunaan teknologi informasi diantaraya digunakan untuk melakukan penyimpanan file/database, penyusunan jadwal, dan penyelesaian masalah IMB. Sedangkan KPPT Kota Cimahi juga sudah menggunakan teknologi informasi dalam bentuk website. Namun belum selengkap yang digunakan di BPPT Kota Bandung. Teknologi informasi yang digunakan oleh KPPT Kota Cimahi masih sebatas pada pengecekan nomor resi, dan penggunaan website secara umum.

\section{Dimensi Responsiveness (Daya Tangkap)}

Pada dimensi responsiveness kualitas pelayanan dilihat dari daya tangkap sumber daya manusianya. Dimana pada dimensi responsiveness kualitas pelayanan dilihat dari kemampuan petugas layanan dalam membantu pengguna layanan didalam layanan IMB. Pada dimensi responsiveness kualitas pelayanan dilihat dari kemampuan petugas layanan dalam menanggapi keluhan pelanggan, kesegeraan tindakan petugas layanan dalam memberikan bantuan penyelesaian masalah kepada pemohon, kemudahan pelanggan dalam memperoleh akses 
informasi pelayanan, kemampuan petugas layanan dalam memberikan pelayanan secara menyeluruh, dan kenyamanan pengguna layanan dalam mengelurakan pendapat. Kelima indikator ini merupakan cerminan dari kualitas pelayanan IMB, baik itu di BPPT Kota Bandung maupun di KPPT Kota Cimahi. Sebagai penyelenggara pelayanan publik kelima indikator ini perlu diperhatikan. Karena pada dimensi responsiveness lebih menekankan kepada faktor sumber daya manusia. Jadi baik buruknya kualitas pelayanan IMB pada dimensi responsiveness secara keseluruhan dapat dilihat dari faktor manusia.

Berdasarkan dari hasil penelitian yang dilakukan di BPPT Kota Bandung dan KPPT Kota Cimahi, pada dimensi responsiveness terdapat perbedaan kualitas pelayanan IMB. Secara keseluruhan perbedaan tersebut dapat dilihat dari aspek sumber daya manusianya, seperti koordinasi dan beban kerja. Koordinasi antara intansi perlu diperhatikan. Di BPPT Kota Bandung koordinasi merupakan hal yang sangat penting untuk menjalankan pelayanan perizinan. Dengan adanya koordinasi yang baik, dapat mempermudah petugas layanan dalam memberikan pelayanan IMB kepada pengguna layanan. BPPT Kota Bandung menggunakan perangkat teknologi informasi untuk mempermudah koordinasi BPPT Kota Bandung dengan DISTRACIP Kota Bandung sebagai tim teknis. Sedangkan di KPPT Kota Cimahi, masalah koordinasi juga menjadi kendala yang harus diperbaiki, seperti koordinasi KPPT Kota Cimahi dengan Dinas PU Kota Cimahi dalam melayani layanan IMB. Namun koordinasi antara KPPT Kota Cimahi dengan Dinas PU belum menggunakan pendekatan teknologi informasi seperti di BPPT Kota Bandung. Untuk BPPT Kota Bandung selain masalah koorinasi, masalah beban kerja juga menjadi perhatian, sebab beban kerja yang tinggi memperngaruhi daya tanggap petugas layanan dalam melayani pengguna layanan IMB. Sedangan di KPPT Kota Cimahi, beban kerja tidak sebanyak di BPPT Kota Bandung, karena tidak banyak berkas yang harus dikerjakan. Oleh karena itu beban kerja perlu disesuaikan dengan jumlah pegawai yang ada, jangan sampai terjadi overload.

\section{Dimensi Assurance (Jaminan)}

Pada dimensi assurance kualitas pelayanan IMB dilihat dari kemampuan, kesopanan, dan para petugas layanan yang dapat dipercaya, dan kepercayaan diri petugas layanan. Pada intinya dimensi assurance memberikan jaminan pelayanan yang diberikan kepada pengguna layanan atas apa yang diperoleh. Kualitas pelayanan IMB pada dimnesi assurance dapat dilihat dari kesesuaian biaya layanan dengan 
prakteknya, keberadaan pegawai saat melayani, keakuarat data, kecepatan data, kebenaran data, dan ketepatan data. Kelima indikator ini menjadi tolak ukur kualitas pelayanan pada dimensi assurance. Oleh karena itu kelima indikator ini pada dimensi assurance pada kualitas pelayanan IMB perlu diperhatikan oleh BPPT Kota Bandung dan KPPT Kota Cimahi sebagai penyelenggara pelayanan publik. Karena didalam pelayanan publik, penyelenggara pelayanan publik perlu memberikan jaminan kepada pengguna layanan, minimal biaya layanan sesuai dengan prakteknya.

Berdasarkan dari hasil penelitian di BPPT Kota Bandung dan KPPT Kota Cimahi, kualitas pelayanan IMB pada dimensi assurance terdapat perbedaan. Perbedaan kualitas pelayanan IMB antara BPPT Kota Bandung dan KPPT Kota Cimahi terletak pada keberadaan pegawai saat melayani. Dimana BPPT Kota Bandung menyediakan layanan informasi melalui call center, website, dan sosial media. Sedangkan KPPT Kota Cimahi keberadaan pegawai dalam membantu pengguna layanan belum menggunakan layanan media sosial, tetapu masih menggunakan layanan call center dan website. Selain itu keakuratan data di KPPT Kota Cimahi tergolong baik dibadingkan dengan keakuratan data di BPPT Kota Bandung. Keakuratan data di KPPT Kota Cimahi lebih baik dikarenakan berkas layanan yang ada tidak sebanyak dengan berkas layanan di BPPT Kota Bandung. Jadi keakuratan data sangat penting sebagai sumber informasi layanan.

\section{Dimensi emphaty (Empati)}

Kualitas pelayanan IMB pada dimensi emphaty bertujuan untuk melihat sejauh mana perhatian individu dalam memamahi kebutuhan penggan dan sejauh mana hubungan petugas layanan dengan pengguna layanan. Pada dimensi emphaty kualitas pelayanan IMB di BPPT Kota Bandung dan KPPT Kota Cimahi dilihat tujuh indiktaor yang terdiri dari perhatian petugas layanan kepada pengguna layanan, petugas layanan memperlakukan pengguna layanan dengan bertanggung jawab, petugas layanan bersungguh-sungguh menghadapi pengguna layanan. Ketujuh indikator inilah yang menjadi penilaian pengguna layanan untuk menilai baik dan buruknya kualitas pelayanan IMB pada dimensi emphaty.

Berdasarkan dari hasil penelitian yang dilakukan di BPPT Kota Bandung dan KPPT Kota Cimahi, pada dimensi emphaty kualitas pelayanan IMB terdapat perbedaan. Pada dimensi ini, petugas layanan BPPT Kota Bandung menindaklanjuti keluhan-keluhan pelanggan dengan memberika kritik saran melalui survey kepuasan pelanggan. 
Dengan hasil survey ini dapat diketahui kelebihan dan kekuarangan dari kualitas pelayanan IMB di BPPT Kota Bandung. Survey kepuasan pelanggan ini cukup mudah, karena menggunakan pendekatan teknologi informasi melalui layar monitor LED. Sehingga memudahkan pengguna layanan dalam mengikitu survey kepuasan pelanggan. Sedangkan di KPPT Kota Cimahi belum menggunakan LED dalam melakukan survey kepuasan pelanggan. Survey kepuasan pelanggan di KPPT Kota Cimahi belum berjalan seperti di BPPT Kota Bandung. Secara keseluruhan KPPT Kota Cimahi pada dimensi ini lebih menekankan kepada kebutuhan pengguna layanan, seperti informasi layanan perizinan. Perbedaan yang paling menonjol BPPT Kota Bandung dan KPPT Kota Cimahi terlihat dari jumlah personel dalam melayani pengguna layanan. Petugas layanan di BPPT Kota Bandung lebih banyak dari KPPT Kota Cimahi. Sehingga perhatian individu petugas layanan kepada pengguna layanan belum maksimal.

\section{E. KESIMPULAN DAN SARAN}

Berdasarkan dari hasil penelitan diatas dapat dimpulkan bahwa, kualitas pelayanan izin mendirkan bangunan (IMB) antara BPPT Kota Bandung dan KPPT Kota Cimahi yang diukur dari lima dimensi yaitu, dimensi tangible, dimensi reliability, dimensi responsiveness, dimensi assurance, dan dimensi emphaty. Yang secara keseluruah hasilnya BPPT Kota Bandung lebih baik dari KPPT Kota Cimahi berdasarkan dari kelima dimensi tersebut.

Untuk saran, pada dimensi tangible BPPT Kota Bandung perlu meningkatkan kenyamanan fisik seperti gedung, sedangkan KPPT Kota Cimahi perlu melengkapai sarana peralatan penunjang. Pada dimensi reliability BPPT Kota Bandung dan KPPT Kota Cimahi ketepatan waktu perlu ditingkatkan. Dan KPPT Kota Cimahi juga perlu meningkatkan standar pelayanan dengan menggunakan pendekatan teknologi. Pada dimensi responsiveness, baik BPPT Kota Bandung maupun KPPT Kota Cimahi perlu meningkatkan koordinasi. BPPT Kota Bandung perlu memiliki SOP bersama dengan tim teknis, dalam hal ini DISTARCIP Kota Bandung. Sedangkan KPPT Kota Cimahi koordinasi dengan tim teknis seperti Dinas PU, perlu menggunakan sarana teknologi informasi dan SOP bersama untuk memudahkan koordinasi pelayanan IMB. Pada dimensi assurance, baik BPPT Kota Bandung maupun KPPT Kota Cimahi, biaya layanan harus sesuai dengan prakteknya. Biaya layanan harus semurah mungkin bila perlu gratis. Penggunaan sarana teknologi 
informasi juga perlu dimakasimalkan. Dan pada dimensi emphaty, petugas layanan harus lebih berempati kepada pengguna layanan, karena dapat membantu keluhan dan kebutuhan pengguna layanan. Selain itu keluhan-keluhan pelanggan juga perlu ditindaklanjuti, seperti melakukan survey kepuasan pelanggan. Hal ini sangat penting untuk kelancaran penyelenggara pelayanan IMB, baik di BPPT Kota Bandung maupun di KPPT Kota Ciamhi.

\section{Referensi}

Connolly, R., dan Bannister, F. (2008). "Factors Influencing Irish Consumers' Trust in Internet Shopping". Management Research News. Vol.31 No. 5. Pp 339-358.

Davis, M., dan Heineke, J. (2003). Managing Service: Using Technology toCreate Value, Boston: Mc Graw Hill.

Donabedian, A. (1980). Explorations in Quality Assesment and Monitoring, Volume 1. The Definition of Quality and Approaches to its Assessment. Atlanta-George: Health Administration Press.

Feigenbaum A.V. (1991). Total Quality Control. New York: McGraw-Hill.

Gaspersz, V. (1997). Manajemen Kualitas: Penerapan Konsep Vincent dalam Manajemen Bisnis Total. Jakarta: Gramedia Pustaka Utama. (2006). Total Quality Management: untuk Praktisi Bisnis dan Industri. Jakarta: PT. Gramedia Pustaka Utama.

Gerson, R. F. (2002). Mengukur Kepuasan Pelanggan, Panduan Menciptakan Pelayanan Bermutu. Seri Panduan Praktis No 17. Edisi: Bahasa Indonesia dari: Measuring Customer Satisfaction. Alih Bahasa oleh Hesti Widyaningrum. Jakarta: Penerbit PPM.

Gronroos, C. (1983). Strategic Management in the Service Sector. London: Chartwell-Bratt.

House of Common, Commission of Public Account. (2005). Delivering High Quality Public Service of All. 63 Report of Session 2005-06. London. The Stationery Office Limited.

Heizer, J., dan Render, B. (1993). Production and Operation Management. USA: Allyn and Bacon.

Kang, Gi-Du., dan James, J. (2004). Service Quality Dimmensions: An Examination of Gronroos's Service Quality Model. Managing Service Quality. Volume 14 - number 4. Hal 266-277. 
KUALITAS PELAYANAN IZIN MENDIRIKAN BANGUNAN (IMB) ANTARA BADAN PELAYANAN PERIZINAN TERPADU KOTA BANDUNG DAN KANTOR PELAYANAN PERIZINAN TERPADU KOTA CIMAHI

Irvan Arif Kurniawan

Kotler, P., (1994). Marketing Management; Analysis, Planning, Implementation and Control (8th ed). International Edition, Englewood Cliffs, New Jersey: Prentice Hall.

Lembaga Administrasi Negara. (2003). Penyusunan Standar Pelayanan Publik. LAN. Jakarta.

Lehtinen, U., and Lehtinen, J. (1982). Service Quality - A Study of Quality Dimensions. Service Management Institute Helsingfors.

Lovelock, C., dan Wright,L. (1999). Principles of Service Marketing Second edition. New York: Prentice Hall International Inc.

Munhurrun, P. R., et.al. (2010). Service Quality in The Public Sector. International Journal of Management and Marketing Rersearch Vol 3 Number 1. Hal 37-49.

Nazir, M. (2011). Metode Penelitian. Bogor: Ghalia Indonesia.

Rochaety, E., Ridwan. Z. F., \& Setyowati, T. (2013). Sistem Infromasi Manajemen Edisi 2. Jakarta: Mitra Wacana Media.

Rodriguez, G.P., et. al. (2009). Quality Dimensions in the Public Sector: Municipal Service and Citizen Perception. Int. Rev Public Non Profit Mark. 6: 75-90.

Schiffman, K. (1997). Consumer Behaviour. Fifth Edition. New York, USA. Prentice hall. International Edition. Inc.

Sutabri, T. (2012). Konsep Sistem Informasi. Jakarta: Andi Offset

Suuroja, Maive. (2003). Service Quality-Main Conceptualization and Critique. Estonia: Tartu University Press.

Suwardi, Herman. (1996). Nalar; Kontenplasi dan Realita. Bandung: Program Pascasarjana Universitas Padjadjaran.

Triguno. (1997). Budaya Kerja: Menciptakan Lingkungan Kerja yang Kondusif Untuk Meningkatkan Produktivitas Kerja. Jakarta: Golden Tedvon Press.

Tjiptono, F. (1990). Delivering Quality Service: Balancing Customer Preception and Expectation. New York: The Free Press. . (1995). Layanan Prima dalam Bidang Jasa. Yogyakarta: Andi Offset. . (2000). Total Quality Management. Jogkarta: Andi. . (2002). Manajemen Jasa. Yogyakarta: Andi. . (2005). Pemasaran Jasa. Malang: Bayumedia Publishing.

Zeithaml, V. A, Berry. L., dan Parasuraman, A. (1996). The Behavioural Consequences of Service Quality. Journal of Marketing. Vol. 60. Hal 31-46. 
Zeithaml, V., and Bitner. M. J. (2003). Service Marketing: Integrating Customer Fokus Across the Firm (third edition). Singapore: Mc Graw Hill.

Buttle, F. (1995). Servqual: Review, Critique, Research Agenda. European Journal of Marketing. Vol. 30. No. 1. Hal. 8-32.

Dinsdale, G., dan Marson, B. (1999). Citizen/Client Surveys: Dispelling Myths and Redrawing Maps. Citizen-Centered Service Network. Canada: Canadian Centre for Management Development.

McManus, J. J., \& Hutchinson, I. (1996) "TQM in service design", Managing Service Quality: An International Journal, Vol. 6 Iss: 1, pp.40 - 44

Parasuraman, A., Zeithmal, V. A., and Berry, L. L. (1985). A Conceptual Model of Service Quality and its Implications for Future Research. Dalam Journal of Marketing. Vol 49 (Fall 1985), 41-50. . (1988). Servqual: A Multiple-Item Scale for Measuring

Consumer Perception of Service Quality. Journal of Retailing, Vol. 64. pp 1240.

Sudjud, A. (1978). Beberapa Pemikiran Tentang Penelitian Komparasi. Pidato Pengukuhan.

Hasil Observasi Peneliti pada tanggal 13 Agustus - 3 September 2014 di

Pemerintah Kota Bandung dan Pemerintah Kota Cimahi.

http://upetd.up.ac.za/thesis/available/etd-05042009

003506/unrestricted/06chapter7.pdf. Diakses pada tanggal 9

September 2014.

http://news.bisnis.com/read/20140324/78/213344/bangunan-tanpa-imb-di-

bandung-terhitung-tinggi. Diakses pada tanggal 9 September 2014.

http://www.pikiran-rakyat.com/node/185824. Diakses pada tanggal 9

September 2014.

http://jabar.tribunnews.com/2013/11/14/pembuatan-imb-di-cimahi-dinilai-belumefisien. Diakses pada tanggal 9 September 2014.

http://www.inilahkoran.com/read/detail/2070950/warga-cimahi-keluhkan-

permohonan-imb-lamban. Diakses pada tanggal 9 September 2014.

http://www.boss.or.id/ diakses pada tanggal 30/04/2015.

http://www.boss.or.id/index.php?option=com_content\&view=article\&id $=76 \&$ Itemid $=99$ diakses pada tanggal 30/04/2015.

http://49.236.220.101/e-kiosk/ diakses pada tanggal 30/04/20152015 http://id.wikipedia.org/wiki/Kebersihan diakses 30/04/2015.

http://news.okezone.com/read/2014/10/04/340/1048299/malamtakbiran-kantor-bppt-distarcip-kota-bandung-terbakar diakses 01/05/2015. 
KUALITAS PELAYANAN IZIN MENDIRIKAN BANGUNAN (IMB) ANTARA BADAN PELAYANAN PERIZINAN TERPADU KOTA BANDUNG DAN KANTOR PELAYANAN PERIZINAN TERPADU KOTA CIMAHI

$$
\text { Irvan Arif Kurniawan }
$$

http:/ / news.okezone.com/read/2014/10/04/340/1048308/korsletinglistrik-diduga-penyebab-kantor-bppt-kota-bandung-terbakar diakses 01/05/2015.

http://cikalnews.com/read/1355/06/10/2014/kantor-bppt-dandistarcip-terbakar-pelayanan-perizinan-terganggu diakses 01/05/2015.

http:// bppt.bandung.go.id/web/index.php/pages/detail/43-formulir diakses 30/05/2015.

http://kppt.cimahikota.go.id/main/pendaftaran_online2 diakses 30/05/2015.

http://www.cimahikota.go.id/images/pdf/download/fgd2013/PDF/1 1\%20SP\%20IZIN\%20MENDIRIKAN\%20BANGUNAN-2013rev.pdf diakses 15 Juni 2015.

http://www.cimahikota.go.id/images/pdf/download/fgd2013/PDF/1 1\%20SP\%20IZIN\%20MENDIRIKAN\%20BANGUNAN-2013rev.pdf diakses 27 Juni 2015. 